\title{
Immobilization of proteases with a water soluble-insoluble reversible polymer for treatment of wool
}

\author{
Carla J.S.M. Silva ${ }^{\mathrm{a}}$, Qinghua Zhang ${ }^{\mathrm{b}}$, Jinsong Shen ${ }^{\mathrm{b}}$, Artur Cavaco-Paulo ${ }^{\mathrm{a}, *}$ \\ a Department of Textile Engineering, Minho University, 4800-058 Guimarães, Portugal \\ ${ }^{\mathrm{b}}$ Textile Engineering and Materials (TEAM) Research Group, De Montfort University, Leicester LE1 9BH, UK
}

Received 1 March 2005; accepted 17 November 2005

\begin{abstract}
A commercial protease, Esperase, was covalently linked to Eudragit S-100, a reversible soluble-insoluble polymer by carbodiimide coupling. When compared to the native enzyme, the immobilized form presented a lower specific activity towards high molecular weight substrates but a higher thermal stability at all temperatures tested. The optimum $\mathrm{pH}$ of the immobilized protease was shifted towards the alkaline side by about one $\mathrm{pH}$ unit while there was no change in optimum temperature between the free and immobilized protease. The immobilized protease exhibited a good storage stability and re-usability.

Enzymatic treatment of wool using proteases has been investigated for wool shrink-resist finishing. It was found that using the immobilized protease in the enzymatic treatment of wool there was a reduction of weight and fibre tensile strength loss because the proteolytic attack is only limited to the cuticle surfaces of wool fibres. This novel approach is a promising alternative for wool shrink-resist finishing to replace the conventional chlorine treatments. This environmentally friendly bioprocess needs to be further characterized to a complete understanding and optimization.
\end{abstract}

(C) 2005 Elsevier Inc. All rights reserved.

Keywords: Serine proteases; Eudragit; Immobilization; Stability; Wool bio-finishing

\section{Introduction}

Wool fabrics are subjected to a variety of chemical treatments in order to provide them with the desired properties, such as shrinkproofing. The typical commercial shrink-resist finishing used for decades is the Chlorine-Hercosett process. This extremely effective process, widely used even today, consists of a strongly acid chlorine treatment with a subsequent neutralisation and an application of polymer resin [1]. A high level of shrink resistance is conferred to the wool, but polymer finishing changes natural wool character to a more synthetic handle. Contamination of the wastewater with absorbable organic chlorides (AOX) is caused by chlorination and presents severe ecological problems [2]. Hence, there is an urgent need for the development of environmentally friendly processes for wool shrink-resist finishing.

\footnotetext{
* Corresponding author. Tel.: +351 253 510271; fax: +351 253510293

E-mail address: artur@det.uminho.pt (A. Cavaco-Paulo).
}

There have been several attempts to replace these chemical treatments of wool by an environmental friendly enzymatic process [3-5]. Given that proteases can promote the hydrolysis of protein compounds, the enzymatic treatment with proteases may degrade the cuticle scales of wool fibre, which are responsible for the wool textiles tendency to undergo felting and shrinkage. However, the proteolytic attack is not only limited to the fibre surface, since proteases can easily penetrate inside the wool fibre, causing significant weight and tensile strength loss to wool fibres or fabrics [6,7]. Therefore, if proteases were immobilized to increase their sizes sufficiently, the proteolytic attack would be limited to the cuticle scales of wool fibre, allowing for the control of the hydrolysis process. Additionally, the immobilization of enzymes on solid supports by covalent attachment can offer several advantages over the native enzymes including easy handling, recovery from the reaction medium and reuse and/or operation in continuous reactors [8]. However, the proper interaction of the enzyme with a solid substrate such as wool fibres would only occur if the enzyme is in the soluble state. This heterogeneous enzymatic system would be more effective and interesting from an industrial point of view if the enzyme can 
be recovered and reused after the treatment. Recently, the use of soluble-insoluble matrices for enzyme immobilization is being studied, due to the several advantages of this system [9-11]. One of such matrices is Eudragit S-100 which is a polymer that can be made soluble-insoluble by changing the $\mathrm{pH}$, thus making possible the recycling of the enzymes, a major advantage over other methods which use soluble enzymatic matrices.

This study investigated the covalent immobilization of a commercial protease onto the soluble-insoluble reversible polymer Eudragit S-100 by carbodiimide coupling. The stability and activity of the enzymatic conjugate under various storage and operational conditions was evaluated and compared with the native enzyme. Enzymatic treatment for wool shrink-resist finishing using both native and immobilized enzyme was studied, evaluating the degradation of wool fibre by the proteases treatment. The viability of this enzymatic wool bio-finishing process using the reversibly soluble protease was investigated.

\section{Materials and methods}

\subsection{Enzyme, chemicals and wool materials}

\subsubsection{Enzyme and chemicals}

The alkaline protease Esperase (E.C.3.4.21.62), a subtilisin with a broad specificity, was supplied by Novozymes, and Eudragit S-100 was supplied by Degussa-Hüls, S.A., Barcelona. Carbodiimide hydrochloride (EDC) and ethanolamine were purchased from Sigma (St. Louis, USA). All other chemicals used were of analytical grade.

\subsubsection{Wool material}

Untreated pure wool woven fabrics were provided by Albano Antunes Morgado Lda, Portugal. The scoured woven wool fabric used was supplied by Drummond Parkland Ltd. and was a pre-scoured fabric of $23 \mu \mathrm{m}$ mean fibre diameter.

\subsection{Enzyme assay and protein concentration}

The activity of Esperase was measured by incubating $1 \mathrm{ml}$ of diluted soluble enzyme (native or immobilized) with $5 \mathrm{ml}$ of $0.65 \%$ casein solution in $50 \mathrm{mM}$ phosphate buffer, $\mathrm{pH} 7.6$, for exactly $10 \mathrm{~min}$ at $37^{\circ} \mathrm{C}$. The reaction was stopped by addition of $5 \mathrm{ml}$ of $110 \mathrm{mM}$ tricloroacetic acid solution. The precipitate was removed by filtration and centrifugation. Then, $2 \mathrm{ml}$ of filtrate were mixed with $5 \mathrm{ml}$ of $500 \mathrm{mM} \mathrm{Na}_{2} \mathrm{CO}_{3}$ solution and $1 \mathrm{ml}$ of two-fold diluted Folin's reagent. After vigorous mixing, the colour was allowed to develop for $30 \mathrm{~min}$ at $37^{\circ} \mathrm{C}$. The absorbance due to the amino acids produced was analysed at $660 \mathrm{~nm}$, based on DL-tyrosine as standard. One unit of activity is defined as the amount of enzyme that hydrolyses casein to produce equivalent colour to $1 \mu \mathrm{mol}$ of tyrosine per minute at $\mathrm{pH} 7.6$ and $37^{\circ} \mathrm{C}$ (colour by the Folin \& Ciocalteu's reagent).

The total protein concentration was determined by the modified micro Lowry method [12], using bovine serum albumin as standard and Sigma test kit no. P5656.

\subsection{Immobilization of Esperase onto Eudragit}

The protease was covalently linked to Eudragit S- 100 by carbodiimide coupling. A polymer solution of $2.5 \%(\mathrm{w} / \mathrm{v})$ of Eudragit S-100 was prepared in phosphate buffer $\mathrm{pH} 7.2$ containing $0.28 \mathrm{M}$ of $\mathrm{NaCl}$. The $\mathrm{pH}$ of the solution was raised to 11.3 with the addition of a $\mathrm{NaOH}$ solution and then reduced to pH 7.2 with an $\mathrm{HCl}$ solution. Carbodiimide coupling agent $(0.2 \%$ (w/v) solution) was added into the polymer solution and stirred for $10 \mathrm{~min}$. Then Esperase $(1 \%$, in $\mathrm{v} / \mathrm{v})$ was added. The mixed solution was kept under stirring for $1 \mathrm{~h}$ at room temperature and then mixed with $0.05 \%(\mathrm{v} / \mathrm{v})$ of an ethanolamine solution $(0.45 \mathrm{~g} / \mathrm{ml})$ for $1 \mathrm{~h}$ at room temperature. The $\mathrm{pH}$ of the mixture was reduced to
4.5 with acetic acid for precipitation of Eudragit-enzyme conjugate. The precipitate was separated by centrifugation $(13,000 \times g, 10 \mathrm{~min})$ and washed by re-suspending in $0.01 \mathrm{M}$ acetate buffer containing $0.14 \mathrm{M} \mathrm{NaCl}(\mathrm{pH} 4.5)$ for $10 \mathrm{~min}$ and reprecipitation at $\mathrm{pH} 4.5$. The repeated wash was also carried out further with $0.02 \mathrm{M}$ phosphate buffer containing $0.14 \mathrm{M} \mathrm{NaCl}$ (pH 7.2). Finally, the Eudragit-enzyme precipitate was redissolved in $100 \mathrm{ml}$ of $0.3 \mathrm{M}$ Tris-Cl buffer containing $0.03 \mathrm{M} \mathrm{CaCl}_{2}$ (pH 7.6).

\subsection{Gel electrophoresis}

SDS-PAGE was carried out to separate the proteins and to determine their molecular weights, using the Hoefer miniVe system from Amersham Pharmacia Biotech. The resolving gels ( $10 \%$ acrylamide of about $1.5 \mathrm{~mm}$ thickness) were prepared according to the method originally described by Laemmli [13] and run at a constant voltage $(120 \mathrm{~V})$. The current was stopped when the bromophenol blue dye marker reached about $1 \mathrm{~cm}$ from the bottom of the gel. The resulting gels were silver stained to observe the protein-banding pattern on the gel. Standard proteins, Phosphorylase b (97 kDa), Albumin (66 kDa), Ovalbumin (45 kDa) and Trypsin inhibitor $(20.1 \mathrm{kDa})$, were used for calibration.

\subsection{Effect of $p H$ and temperature on enzyme activity}

The effect of temperature and $\mathrm{pH}$ on the activity of native and immobilized Esperase was investigated. The enzymes were incubated with casein in $0.3 \mathrm{M}$ Tris- $\mathrm{Cl}$ buffer containing $0.03 \mathrm{M} \mathrm{CaCl}_{2}$ at $\mathrm{pH} 7.6$ and various temperatures ranging from 20 to $100^{\circ} \mathrm{C}$, and alternatively incubated at $37^{\circ} \mathrm{C}$ and various $\mathrm{pH}$ from 4 to 12 , using Britton-Robinson buffer with $\mu=0.3 \mathrm{M}$. The activity of proteases at different $\mathrm{pH}$ and temperatures was then measured according to the method described in Section 2.2.

\subsection{Reusability}

The initial activity of the immobilized enzyme was measured and the conjugate was then subjected to five cycles of repeated use. After each run the immobilized enzyme was recovered by lowering the $\mathrm{pH}$ to 4.5 , centrifugation, alternative washing of the precipitated polymer with acetate buffer $\mathrm{pH} 4.5$ and phosphate buffer $\mathrm{pH} 7.2$ and re-dissolution in Tris-Cl buffer, $\mathrm{pH}$ 7.6. The activity was measured after the first, third and fifth cycles.

\subsection{Determination of enzyme stability}

For testing the storage stability of enzymes, both native and immobilized Esperase were stored in a refrigerator at $4{ }^{\circ} \mathrm{C}$ or at room temperature at ca. $20^{\circ} \mathrm{C}$ for several days. Then the remaining activity of the enzymes was measured at $\mathrm{pH}$ 7.6, according to the method described in Section 2.2. For operational stability, the enzymes were placed in a water bath at $37^{\circ} \mathrm{C}\left(\mathrm{pH} 7.6\right.$ or 10.0) or $60^{\circ} \mathrm{C}(\mathrm{pH}$ 7.6) under $90 \mathrm{rpm}$ of stirring for several hours. Then the remaining activity was measured at $37^{\circ} \mathrm{C}$.

The stabilization factor (SF) was calculated as the ratio of the half-life of the immobilized enzyme to that of the corresponding native enzyme.

\subsection{Wool pre-treatments and enzymatic treatments}

Woven fabrics of $100 \%$ wool (Albano Antunes Morgado Lda, Portugal) were scoured in an aqueous solution containing $1 \mathrm{~g} / \mathrm{l}$ non-ionic surfactant Lutensol ON 30 (BASF, Germany) in $0.1 \mathrm{M} \mathrm{Na}_{2} \mathrm{CO}_{3} / \mathrm{NaHCO}_{3}$ buffer $\mathrm{pH} 9.0$ at a liquor to fibre ratio of $20 \mathrm{ml} / \mathrm{g}$ and $40^{\circ} \mathrm{C}$ for $30 \mathrm{~min}$ in a Rota-wash machine (MKII Series 7227, Shirley Developments Ltd., England). After scouring, the fabrics were rinsed with tap water and then distilled water. The scoured fabrics were further bleached in the same machine and liquor ratio with $1 \%$ o.w.f. (of weight of fabric) $\mathrm{H}_{2} \mathrm{O}_{2}$ in $0.1 \mathrm{M} \mathrm{Na}_{2} \mathrm{CO}_{3} / \mathrm{NaHCO}_{3}$ buffer at $\mathrm{pH} 9.0$ and $55^{\circ} \mathrm{C}$ for $1 \mathrm{~h}$. Finally, the wool fabrics were abundantly washed with distilled water and allowed to air dry.

Enzymatic treatment of scoured and bleached wool fabrics was performed in $0.3 \mathrm{M}$ Tris-Cl buffer with $0.03 \mathrm{M} \mathrm{CaCl}_{2}, \mathrm{pH} 7.6$ at the liquor to fibre ratio of $14 \mathrm{ml} / \mathrm{g}$. The native or modified Esperase was added (approximately $100 \mathrm{U}$ of 
activity) and treatments were conducted at $37^{\circ} \mathrm{C}$ with $90 \mathrm{rpm}$ of stirring for $72 \mathrm{~h}$. Wool fabrics were then subjected to three machine washing cycles, according to standard EN 26330. The final weight loss was measured after the machine washings.

Alternatively the scoured woven wool fabric (Drummond Parkland) was enzymatically treated with various low concentrations of native and modified Esperase in $0.02 \mathrm{M}$ sodium tetraborate buffer at $\mathrm{pH} 8.5$ and $65^{\circ} \mathrm{C}$ at the liquor to fibre ratio of $47 \mathrm{ml} / \mathrm{g}$ for $4 \mathrm{~h}$ in a laboratory Roaches washwheel dyeing machine.

\subsection{Weight Loss}

Wool fabrics were conditioned at $100{ }^{\circ} \mathrm{C}$ for $2 \mathrm{~h}$, desiccated and weighed until constant weight (considered as differences between successive weights inferior to $1 \mathrm{mg}$ ). The measurements were carried out in duplicate.

\subsection{Tensile strength resistance and dimensional stability}

The tensile properties of wool samples were determined using a SDL tensile tester equipped with a load cell having a maximum capacity of $2 \mathrm{kgf}$. Also, a test speed of $100 \mathrm{~mm} / \mathrm{min}$, a yarn gauge length of $10 \mathrm{~mm}$ and a linear density of 71.4 Tex were applied.

Wool fabric shrinkage was determined after one $7 \mathrm{~A}$ and five $5 \mathrm{~A}$ wash cycles according to Woolmark method TM31 in the Electrolux Wascator machine.

\section{Results and discussion}

Enzymatic wool finishing processes using proteases are still not commercially available at an industrial level due to several problems such as wool heterogeneity (wool varies with animal, source, feeding, etc.) and the difficulty in controlling the enzyme hydrolysis. Thus, by immobilizing the enzymes in soluble matrices, one could overcome some of these problems, making process control feasible and easy, therefore limiting the damage of the fibre [3].

\subsection{Effect of $p H$ and temperature on enzyme activity}

Fig. 1 shows the effect of $\mathrm{pH}$ and temperature on the relative activity of the immobilized and native Esperase. As shown in (Fig. 1a), maximum enzyme activity was observed in the alkaline region, as expected for proteases from Bacillus sp. [14]. The optimal $\mathrm{pH}$ is shifted from about 9.5 to $10.5 \mathrm{pH}$ units upon immobilization. In earlier studies, an increase in optimum $\mathrm{pH}$
Table 1

Half-life times $\left(t_{1 / 2}\right)$ for the native and modified Esperase at various temperatures

\begin{tabular}{lccr}
\hline Temperature & Native Esperase & Immobilized Esperase & $\mathrm{SF}^{\mathrm{a}}$ \\
\hline $4{ }^{\circ} \mathrm{C}$ & $140 \pm 33$ days & $770 \pm 260$ days & 5.5 \\
$\mathrm{RT}$ & $8 \pm 1$ days & $54 \pm 10$ days & 6.8 \\
$37^{\circ} \mathrm{C}(\mathrm{pH} \mathrm{7.6)}$ & $1.4 \pm 0.2$ days & $19 \pm 2$ days & 13.6 \\
$37^{\circ} \mathrm{C}(\mathrm{pH} \mathrm{10)}$ & $5.0 \pm 0.6$ days & $17 \pm 2$ days & 3.4 \\
$60^{\circ} \mathrm{C}$ & $0.58 \pm 0.04 \mathrm{~h}$ & $7.3 \pm 0.5 \mathrm{~h}$ & 12.6 \\
\hline
\end{tabular}

${ }^{\text {a }}$ Stabilization factor (SF) as a ratio of half-life times.

was observed with papain immobilized on an enteric polymer [15], chymotrypsin immobilized on Eudragit S-100 [16] and an alkaline protease immobilized on vermiculite [17]. Sharma et al. [16] explained this $\mathrm{pH}$ shift toward the alkaline region by the anionic nature of the matrix.

The activity of native and immobilized Esperase in Eudragit $\mathrm{S}$-100 increased up to $70^{\circ} \mathrm{C}$ and then decreased with further increases in temperature (Fig. 1b). Therefore, the optimum temperature for Esperase was found to be around $70^{\circ} \mathrm{C}$ for both enzymatic forms. The chemical coupling of the enzyme to the smart polymer Eudragit does not change its temperature profile. Similar results were also obtained with an alkaline protease immobilized on vermiculite [17].

\subsection{Operational and storage stabilities of the enzymes}

From a commercial point of view, the thermal stability of enzymes is one of the most important features for the application of the biocatalyst. The effect of the immobilization of Esperase on its thermal stability was investigated. Table 1 shows the operational and storage stability of the native and immobilized Esperase at $4{ }^{\circ} \mathrm{C}$, room temperature, 37 and $60{ }^{\circ} \mathrm{C}$.

It is interesting to find that there was a significant decrease in inactivation of the immobilized enzyme when compared to the native protease. The stabilization factor was considerably high, ranging from 3.4 to 13.6 .

At $4{ }^{\circ} \mathrm{C}$, the protease is quite stable $\left(t_{1 / 2}\right.$ for native Esperase is 140 days). After immobilization, the enzyme increased its half-life time about five-fold. At room temperature, the protease stability decreases considerably, as expected, but the
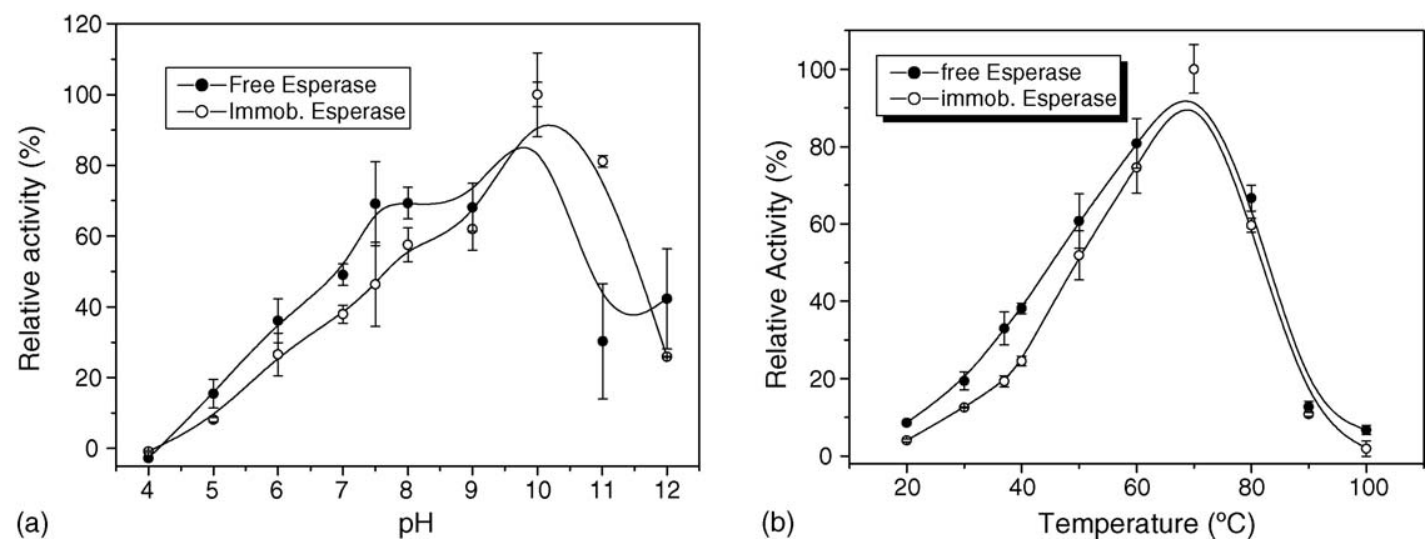

Fig. 1. Effect of $\mathrm{pH}$ (a) and temperature (b) on the relative activity of the native and immobilized Esperase. 
immobilization brought big increases in $t_{1 / 2}$ (stabilization factor is 6.8).

At $37^{\circ} \mathrm{C}$, the half-life time for the native and immobilized Esperase was evaluated at $\mathrm{pH} 7.6$ and 10.0. It was observed that native Esperase was more stable at $\mathrm{pH} 10.0$ than at $\mathrm{pH}$ 7.6. This result confirms the alkaline nature of this enzyme. The immobilized Esperase presented a higher stability at $\mathrm{pH}$ 7.6 (the stabilization factor is 13.6). At $\mathrm{pH} 10.0$, the increase in the stabilization factor was smaller because this is the enzyme optimum $\mathrm{pH}$ and thus no considerable changes will arise at this $\mathrm{pH}$.

The operational stability at $60{ }^{\circ} \mathrm{C}$ was greatly improved by immobilization. After $0.6 \mathrm{~h}$ at this temperature native Esperase had only half of its initial activity, while modified Esperase still retained around $98 \%$ of its initial activity $\left(t_{1 / 2}\right.$ at $60^{\circ} \mathrm{C}$ is $\left.7.3 \mathrm{~h}\right)$.

Thus, the thermal inactivation of immobilized Esperase is much lower than that of native Esperase, both at low and high temperatures. The improved stability of immobilized enzymes may be related to the prevention of autolysis [16] and thermal denaturation $[8,18]$. The immobilization of the enzyme causes an increase in enzyme rigidity, which is commonly reflected by an increase in stability towards denaturation by raising the temperature. In conclusion, the immobilized proteases into Eudragit present an improved thermal stability and thus may be attractive biocatalysts for industrial purposes.

\subsection{Kinetics of enzyme reactions}

In order to better understand the interactions between the proteases and wool fibres, the high molecular weight substrate casein was used as a model representative substrate in the experiments. The catalytic activity of the native and immobilized Esperase towards casein was assessed (Fig. 2). In all the cases, Michaelis-Menten kinetics was observed and its parameters were determined.

The Michaelis-Menten parameters for the native and immobilized enzyme, at $37^{\circ} \mathrm{C}$, were attained by the hyperbolic regression and are listed in Table 2. The $V_{\max }$ values decreased

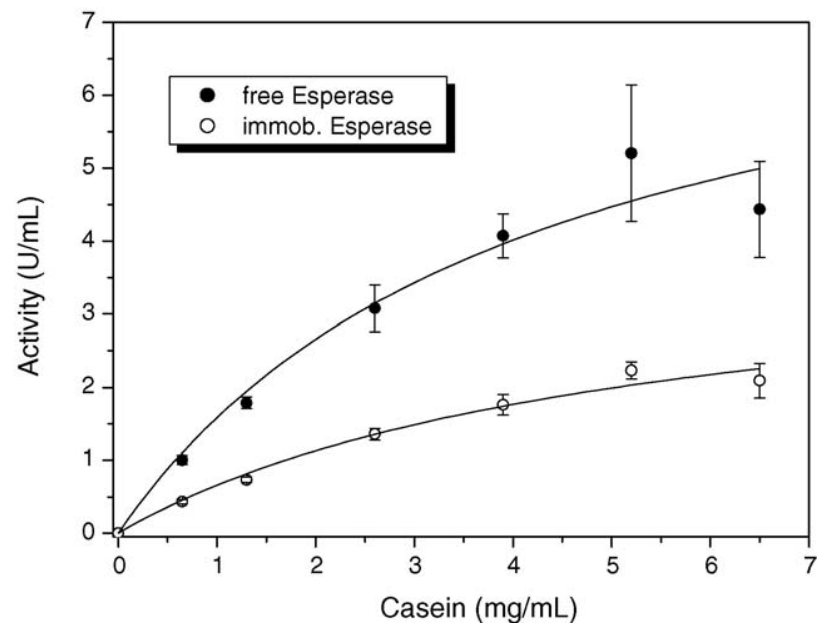

Fig. 2. Comparison of activity of native and immobilized Esperase towards different substrate (casein) concentrations, at $\mathrm{pH} 7.6$ and $37^{\circ} \mathrm{C}$.
Table 2

Kinetic parameters for casein hydrolysis with native and immobilized Esperase (determined by hyperbolic regression)

\begin{tabular}{lll}
\hline Enzyme & \multicolumn{2}{l}{ Esperase } \\
\cline { 2 - 3 } & $V_{\max }(\mathrm{U} / \mathrm{ml})$ & $K_{\mathrm{M}}(\mathrm{mg} / \mathrm{ml})$ \\
\hline Native & $8.2 \pm 1.7$ & $4.2 \pm 1.7$ \\
Immobilized & $4.0 \pm 0.7$ & $5.2 \pm 1.6$ \\
\hline
\end{tabular}

upon immobilization (from 8.2 to $4.0 \mathrm{U} / \mathrm{ml}$ ) while $K_{\mathrm{M}}$ values increased upon immobilization (from 4.2 to $5.2 \mathrm{mg} / \mathrm{ml}$ ). Increases in $K_{\mathrm{M}}$ values upon immobilization have been frequently reported when the matrix is insoluble [19] or soluble [20], but also with these smart polymers. An increase in $K_{\mathrm{M}}$ values was observed when trypsin was coupled to Eudragit S-100 [11], and when xylanase was immobilized on the same polymer, increases in $K_{\mathrm{M}}$ values from 3.6 to $5.0 \mathrm{mg} / \mathrm{ml}$ for the substrate xylan were verified [10].

Comparison of the $K_{\mathrm{M}}$ value for a given free and immobilized enzyme provides information about the interaction between enzyme and its support. An increase in $K_{\mathrm{M}}$ once an enzyme has been immobilized indicates that the immobilized enzyme has an apparent lower affinity for its substrate than that of the native enzyme, which may be caused by the steric hindrance of the active site by the support, or the loss of enzyme flexibility necessary for substrate binding. So, the $V_{\max }$ value of immobilized enzyme is lower than that of the native enzyme.

\subsection{Molecular weight determination}

SDS-PAGE electrophoresis was carried out to investigate the effect of immobilization with Eudragit on the molecular weight of the enzymes. Fig. 3 shows the electrophoresis pattern of the native and immobilized Esperase. It was confirmed that the native Esperase has a molecular weight around 20.1 kDa responsible for the band on the same level for the standard Trypsin. In the channel for the immobilized Esperase, a big diffuse band is shown at the beginning of the resolving gel with a molecular weight above $97 \mathrm{kDa}$. The faint band is also visible at the level of molecular weight of $20.1 \mathrm{kDa}$. It is suggested that the immobilization of Esperase with Eudragit increased the molecular weight of protease which could be higher than $97 \mathrm{kDa}$ but a small trace amount of native Esperase is still present. This trace of Esperase might have escaped the washing process due to absorption on Eudragit. Some studies report that this noncovalently bounded enzyme can be removed with additional washing steps using surfactants such as Triton X-100 [9,11,21]. This test confirms that the higher molecular weight of the immobilized Esperase has been achieved.

\subsection{Reusability of enzymatic preparations}

The reusability of the alkaline protease immobilized on Eudragit S-100 has also been studied because of its importance for industry to reduce the processing costs. The decline in activity on repeated use of immobilized Esperase is given 


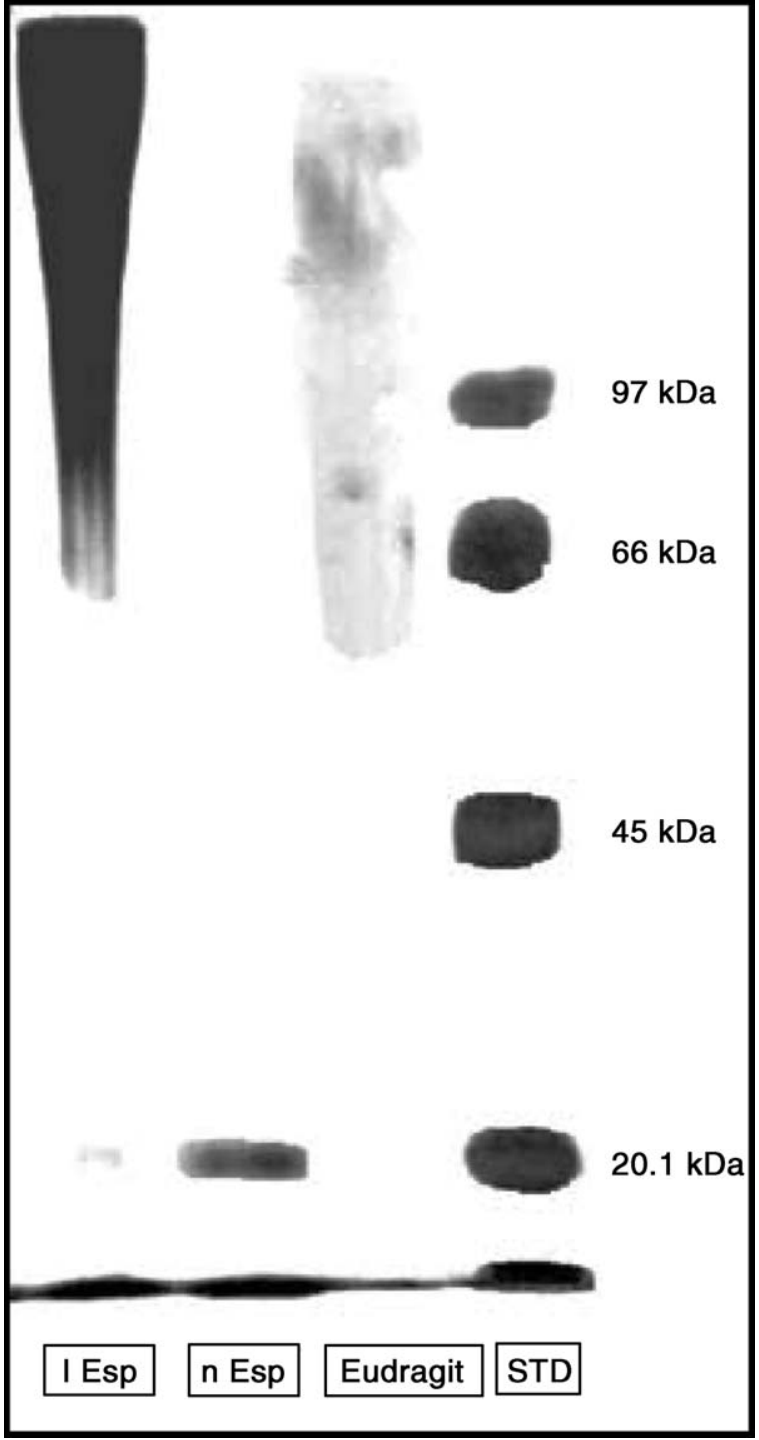

Fig. 3. SDS-PAGE pattern of the native and modified Esperase. Lane 1: modified Esperase; lane 2: native Esperase; lane 3: Eudragit alone; lane 4: molecular-mass markers.

in Fig. 4. The Eudragit-Esperase conjugate retained $72 \%$ of its original activity after five cycles of repeated uses, showing a high reusability.

\subsection{Enzymatic treatments of wool with immobilized Esperase}

The wool fabrics were treated with native and immobilized Esperase at $37^{\circ} \mathrm{C}$ and $\mathrm{pH} 7.6$ for $72 \mathrm{~h}$, followed by three consecutive machine washing cycles. The fabrics were treated using the same enzyme units in the water bath. This means that the effect of the enzymes is directly related and compared. Fig. 5 shows the weight losses of wool fabrics caused by the enzymatic treatment and subsequent washing.

Wool fabrics treated with native Esperase and subjected to three washing cycles present the worst weight loss (about 37\% when enzymatic treatment was applied on scoured and bleached

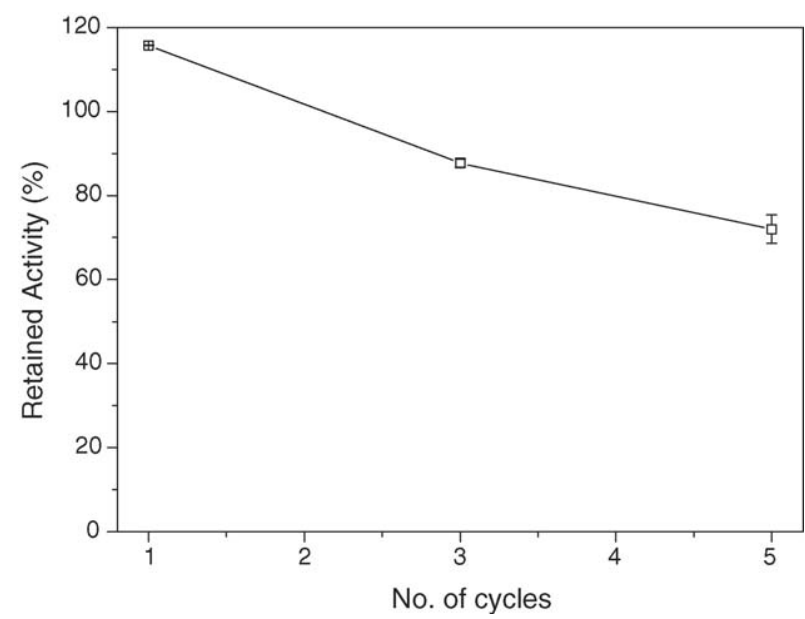

Fig. 4. Retained activity of the immobilized Esperase (in \%) after several cycles of repeated use (initial activity was taken as $100 \%$ ).

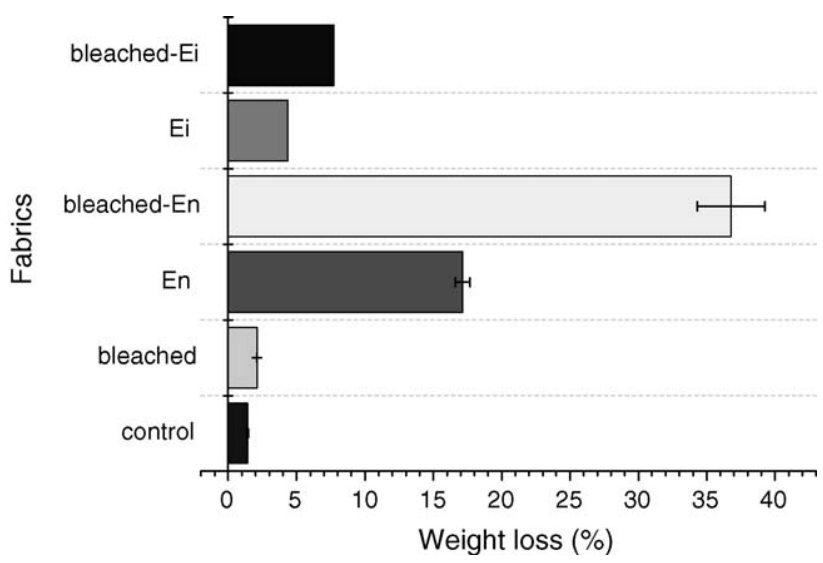

Fig. 5. Effect of enzymatic treatment and subsequent three machine washing cycles on the weight loss of the wool fabrics. En: treated with native Esperase; Ei: treated with immobilized Esperase; bleached: scoured and bleached wool fabric; control: unscoured wool fabric.

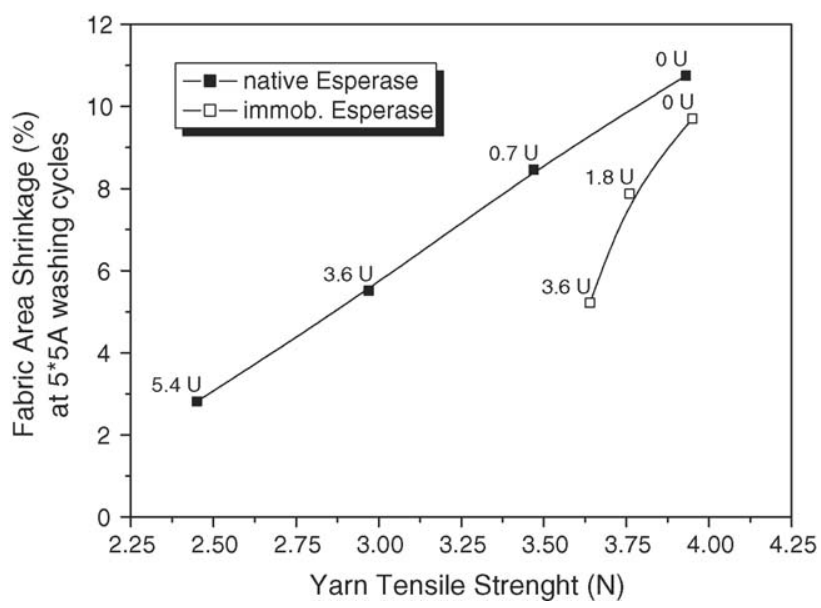

Fig. 6. Effect of enzyme treatment with native or modified Esperase on scoured wool fabrics with increasing amounts of enzyme (measured as total enzyme units in the bath treatment). 
fabric and about $17 \%$ when no pre-treatment was used). The immobilized enzyme did considerably less damage to the wool fabric (the weight losses are in the order of 7 and 4\%, respectively, for the same conditions). Also, the damage caused by the pre-treatment alone is insignificant (weight loss less than 2\%) and can be neglected.

These results confirm that the pre-treatment makes the substrate (wool) more accessible to the proteolytic attack, since the weight loss was significantly higher for the wool fabrics that were pre-treated before the enzymatic treatment. In the case of native Esperase, this difference is more than double and the fabric was extremely degraded after this treatment in severe conditions. Interestingly, using the exact same treatment conditions and the same activity units of immobilized Esperase, the final weight loss was only in the order of $7 \%$, which is a significant difference. This confirms the viability in using this immobilized protease for the purpose of wool finishing, using adequate treatment conditions in a way that the desired effects can be achieved.

The wool fabrics were also subjected to tensile strength and felting shrinkage tests $(5 \times 5 \mathrm{~A}$ wash cycles $)$, after a moderate enzymatic treatment. Fig. 6 shows the results of these parameters on wool fabrics treated with increasing amounts of enzyme activity.

Analysing Fig. 6, it is possible to see that when $3.6 \mathrm{U}$ of activity were used in the wool enzymatic treatment, an area shrinkage of about 5\% was achieved, both for free and immobilized Esperase. This means a reduction to about half of the initial shrinkage. The main differences, however, were verified in the fabric resistance, since with the immobilized Esperase the resistance was still $92 \%$ of its original value, while the native enzyme promoted a loss of about $25 \%$ in the original tensile strength of the wool fabric. The more native enzyme added to the bath treatment, the more intensive was the tensile strength loss of the fabric. This fact was not verified in the fabric treated with the immobilized form (an almost vertical line is observed). This means that when treating wool with the immobilized Esperase, by the proper choice of treatment conditions, one can achieve good levels of shrink resistance without considerably damaging the fabric, by the limitation of degradation to the fibre cuticle cells of wool during enzymatic treatments. The weight loss was in the order of $3 \%$ for the wool treated with immobilized Esperase (data not shown).

Fig. 7 shows the SEM microscopy of wool fabrics treated with native Esperase or the immobilized Esperase. The enzymatic degradation of wool fibres by native Esperase was quite significant. SEM pictures show that the fibres suffered much less damage in the enzymatic treatment using the immobilized Esperase, meaning that the impact of degradation can be controlled by the conditions of treatment. The explanation for this degradation may lie in the fact that there is still free enzyme in the immobilized matrices, as stated previously. This non-covalently bounded enzyme can be removed by additional washing steps prior to the wool enzymatic treatment, as already referred. The fibres that were not degraded presented their cuticle layer removed, thus they have their properties improved.

\section{Conclusions}

A commercial available alkaline protease was coupled to Eudragit S-100, a polymer that is soluble-insoluble, by covalent binding using carbodiimide. The optimum $\mathrm{pH}$ of the immobilized enzyme was shifted to a higher value, but the optimum temperature was unchanged. The operational and storage stability of Esperase was considerably improved by immobilization. The changes in the Michaelis-Menten parameters indicate the existence of steric hindrance effects, but since the conjugate is considerably more stable and shows a high reusability, the immobilized preparations are interesting from an industrial point of view. The wool fabrics treated with immobilized Esperase showed a lower weight loss and a considerably higher tensile strength resistance than the fabrics treated with the native enzyme.

In addition to the simplicity of this immobilization method, these enzyme conjugates are a promising approach for wool (a)

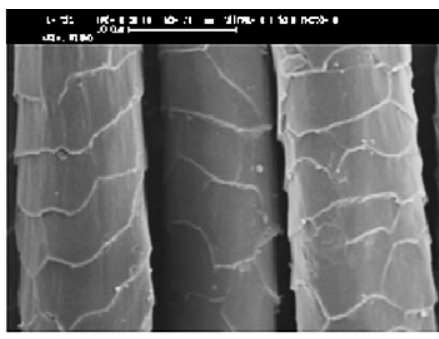

(c)

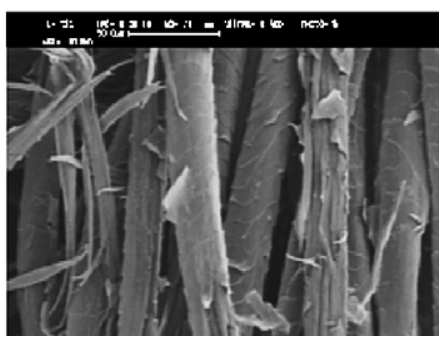

(b)

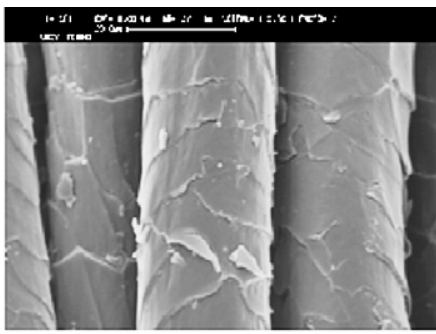

(d)

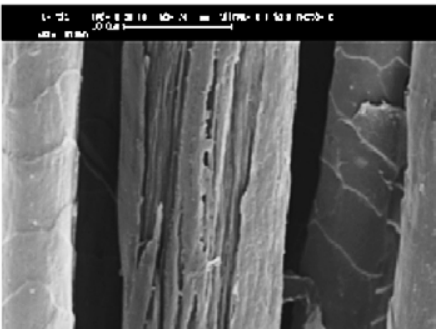

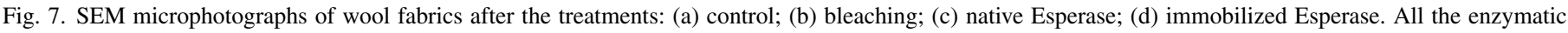
treatments were performed using the same enzyme units in the bath (about $100 \mathrm{U}$ ). 
bio-finishing processes, since they can remove wool cuticles, improving wool properties and can overcome the wool finishing problems with soluble proteases and the environmental problems with the wool chemical treatments. Furthermore, the Eudragit polymer used as an immobilization matrix for enzymes has several attractive features. It is non-toxic (enteric polymer), water soluble, recoverable from solution by switching $\mathrm{pH}$, economical and commercially available [22]. This novel approach for wool shrink-resist process needs to be further characterized for completely understanding and optimization.

\section{Acknowledgements}

The authors are grateful for the EU funding for PROTEX project (G1RD-CT-2002-00695) and the funding by FCT (Portugal) for the PhD fellowship (PRAXIS XXI, SFRH/BD/1292/2000).

\section{References}

[1] Bearpark I, Marriott FW, Park J. A practical introduction to the dyeing and finishing of wool fabrics. Bradford: Society of Dyers and Colourists; 1986.

[2] Cortez J, Bonner PLR, Griffin M. Application of transglutaminases in the modification of wool textiles. Enzyme Microb Technol 2004;34:64-72.

[3] Silva CJSM, Cavaco-Paulo A. Treatment of animal hair fibers with modified proteases. WO03097927, 2003.

[4] Silva CJSM, Sousa F, Gübitz G, Cavaco-Paulo A. Chemical modifications on proteins using glutaraldehyde. Food Technol Biotechnol 2004;42(1):51-6.

[5] Nolte H, Bishop DP, Höcker H. Effects of proteolytic and lipolytic enzymes on untreated and shrink-resist-treated wool. J Text Inst 1996;87(1):212-26.

[6] Heine E, Hollfelder B, Shen J, Bishop D. Parameters affecting the morphology of wool during enzyme treatment. In: 10th International Wool Textile Research Conference. 2000.

[7] Shen J, Bishop D, Heine E, Hollfelder B. Some factors affecting the control of proteolytic enzyme reactions on wool. J Text Inst 1999; 90(3):404-11.
[8] Ferreira L, Ramos MA, Dordick JS, Gil MH. Influence of different silica dericatives in the immobilization and stabilization of a Bacillus licheniformis protease (Subtilisin Carlsberg). J Mol Catal B: Enzymatic 2003;21:189-99.

[9] Rodrigues AR, Cabral JMS, Taipa MA. Immobilization of Chromobacterium viscosum lipase on Eudragit S-100: coupling, characterization and kinetic application in organic and biphasic media. Enzyme Microb Technol 2002;31:133-41.

[10] Sardar M, Roy I, Gupta MN. Simultaneous purification and immobilization of Aspergillus niger xylanase on the reversibly soluble polymer Eudragit $^{\mathrm{TM}}$ L-100. Enzyme Microb Technol 2000;27:672-9.

[11] Arasaratnam V, Galaev IY, Mattiasson B. Reversibly soluble biocatalyst: optimization of trypsin coupling to Eudragit S-100 and biocatalyst activity in soluble and precipitated forms. Enzyme Microb Technol 2000;27:254-63.

[12] Lowry OH, Rosenberg WJ, Farr AL, Randell RJ. Quantitation of protein using Folin Ciocalteau reagent. J Biol Chem 1951;193:265-75.

[13] Laemmli UK. Cleavage of structural proteins during assembly of head of bacteriofage-T4. Nature 1970;227:680-5.

[14] Banerjee UC, Sani RK, Azmi W, Soni R. Thermostable alkaline protease from Bacillus brevis and its characterization as a laundry detergent additive. Process Biochem 1999;35:213-9.

[15] Fujimura M, Mori T, Tosa T. Preparation and properties of soluble-insoluble immobilized proteases. Biotechnol Bioeng 1987;29: $747-52$.

[16] Sharma S, Kaur P, Jain A, Rajeswari MR, Gupta MN. A smart bioconjugate of chymotrypsin. Biomacromolecules 2003;4:330-6.

[17] Chellapandian M. Preparation and characterization of alkaline protease immobilized on vermiculite. Process Biochem 1998;33(2):169-73.

[18] He Z, Zhang Z, He M. Kinetic study of thermal inactivation for native and methoxypolyethylene glycol modified trypsin. Process Biochem 2000;35:1235-40.

[19] Zhou QZK, Chen XD. Immobilization of $\beta$-galactosidase on graphite surface by glutaraldehyde. J Food Eng 2001;48:69-74.

[20] Zacchigna M, Di Luca G, Lassiani L, Varnavas A, Boccù E. Properties of methoxy(polyethylene glycol)-lipase from Candida rugosa in organic solvents. II Farmaco 1998;53:758-63.

[21] Silva CJSM, Gübitz G, Cavaco-Paulo A. Optimization of a serine protease coupling to Eudragit S-100 by experimental design techniques. J Chem Technol Biotechnol 2006;81:8-16.

[22] Kumar A, Gupta MN. Immobilization of trypsin on an enteric polymer Eudragit S-100 for the biocatalysis of macromolecular substrate. J Mol Catal B: Enzymatic 1998;5:289-94. 